\title{
ÚJ SZAK A PEDAGÓGUSKÉPZÉSBEN EGY NAGYHAGYOMÁNYÚ INTÉZMÉNYBEN
}

\author{
ILLÉS ANIKó \\ a Moholy-Nagy Mủvészeti Egyetem \\ egyetemi docense \\ anikoilles@gmail.com
}

A Moholy-Nagy Művészeti Egyetem (korábbi nevén Magyar Iparmüvészeti Egyetem illetve Magyar Iparmüvészeti Főiskola) 24 éve, 1985-ben indította a tanárképzést. Ettől kezdve az iparmüvész hallgatók a művészképzéssel párhuzamosan rajztanításra jogosító egyetemi szintü tanárképzést is kaphattak. (Középiskolai rajztanításra jogosító diplomát ezen kívül csak a Magyar Képzőmüvészeti Egyetemen lehetett szerezni.) Az egyetemi szintü diploma birtokosát feljogosította az ábrázoló geometria, a környezetkultúra, a müvészeti rajz, a müvészettörténet, a rajz és a vizuális kultúra, illetve az elnevezésében eltérő, de tartalmában megegyező tantárgyak középfokú tanítására és vizsgáztatására úgy a közoktatásban, mint a szakképzésben.

A képzés elindítása hatással volt a hazai rajztanítás szemléletének alakulására is. Az addig kizárólag képzőművészet-centrikus rajztanításban megjelent a tárgyés környezetkultúra, valamint a vizuális kommunikáció is. Ez végül az új Nemzeti Alaptantervben világosan manifesztálódott, amennyiben a korábbi rajz tantárgyat felváltotta a „vizuális kultúra” müveltségterület. Az Egyetem Tanárképző Intézete a 90-es években komoly szerepet játszott a NAT kidolgozásában és implementációjában. Számos továbbképzést szervezett, hogy az új szemléletet is feltételező vizuális kultúra tanítására felkészítse a rajztanárokat.

A továbbképzések színvonalát mutatja, hogy a '90-es évek elején meghirdetett 120 órás intenzív pedagógus továbbképzésre több mint 700-an jelentkeztek, így a 20 fős csoportok beiskolázása három évig tartott. A sok hallgatóhoz sok tanár is kellett, így a viszonylag kis létszámú intézet szakértői holdudvara igencsak megnövekedett. Az aktuális igények újabb továbbképzések indításához vezettek. A médiapedagógia, a múzeumpedagógia, a müvészetterápia témájában, így 2000-ig több mint 1000 pedagógus vehetett részt a tanárszak hétféle tanfolyamán.

1990-től évente 20-25 hallgató végzett a nappali képzésben, és ennél sokkal többen levelező hallgatóként. A 120 órás továbbképzésekből nőtt ki az egyetemi diplomát adó továbbképzések rendszere is. Bár a közoktatási törvény elöírta, hogy csak egyetemi végzettségü tanár érettségiztethet, mégsem volt az országban olyan egyetem, ahol az általános iskolai tanításra képesített főiskolai végzettségü rajztanárok középiskolai tanári képesítést szerezhettek volna, olyan pedig egyáltalán 
nem, ahol a vizuális alapműveltség az alkalmazott mủvészetre épült volna ${ }^{1}$. Ezért jött létre 1994-ben a Tanárképző Tanszéken a levelező tagozatos „,vizuális és környezetkultúra" szakos tanárképzés. A hároméves, 1140 órás képzések több szakirányban folynak, így a médiapedagógia, a vizuális kommunikáció tanitása, a textil tanitása területén. Összességében több mint félezren szereztek itt vizuális és környezetkultúra szakos középiskolai tanári diplomát.

A Magyar Iparmüvészeti Egyetem Tanárképző Intézete (később Tanszéke) országos hatáskörủ vizuális nevelési központtá vált. A vizuális nevelés új feladatainak teljesítését a Tanárképző Tanszék nem csak a továbbképzésekkel segítette. Innen indult a tanszékvezető, Gaul Emil kezdeményezésére a „Tölgyfa-program” a Bodóczky István szakmai irányításával létrehozott komplex, a közoktatás 12 évét felölelö vizuális nevelési program, amely tantervet és kiadványokat (tankönyveket, feladatgyüjteményeket, tanári segédkönyveket) tartalmazott, továbbá kiterjedt a pedagógusok felkészítésére is. A program keretében 18 kiadvány jelent meg.

Ugyancsak a rajztanárok tájékozódását segíti a tanszék oktatója, Bodóczky István szerkesztésében 2004-ben indított vizuális nevelési lap, az irány.hu. A negyedévenként megjelenő folyóirat az új tanítási módszerek és a kortárs vizuális kultúra megismertetését igyekszik elősegíteni. A lap szerzői - önkéntes alapon - az ország különböző területein müködő tanárok.

1994-ben Kárpáti Andrea vezetésével a tanszéken hozták létre a Vizuális Nevelési Gyüjteményt. A négyezer eredeti gyermekmunka, az ötezer darabos diatár és a szakkönyvtár a gyermekek és fiatalok vizuális képességeinek fejlődésével, a rajztanítás történetével és napjaink innovatív vizuális nevelési programjaival ismerteti meg az érdeklődőket, a téma kutatóit.

Mivel rajzból nem volt Országos Középiskolai Tanulmányi Verseny 1996-tól a tanszék Zombori Béla vezetésével évenként megszervezte és lebonyolította az országos középiskolai Vizuális Versenyt és Kiállitást. A verseny 2005-ben elnyerte a Rajz és Vizuális Kultúra Országos Középiskolai Tanulmányi Verseny rangját, és a továbbiakban ebben a formában jelenik meg.

A tanszék máig meghatározó mühelye a hazai vizuális nevelési kutatásoknak és fejlesztéseknek, résztvevője több nemzetközi programnak, amelyekből felsorolunk néhányat:

- LEONARDO program - a vizuális nevelés 5 modellje. (KFA 1985/87)

- CITO, holland-magyar rajzi érettségi munkacsoport (MKM 1993/95)

- Wohnkultur und Plattenbau (HdK, Berlin 1991/93)

- Médiaelmélet és médiapedagógia a felsőoktatásban (FEFA 1994)

- A vizuális képességek fejlesztése és értékelése projekt módszerrel. (MKM 1996/97)

\footnotetext{
${ }^{1}$ A '90-es évek elejére már nem müködött a korábban Balogh Jenő által vezetett, sok föiskolai rajztanárnak képesítést nyújtó tanfolyam a Képzőművészeti Főiskolán.
} 
- A vizuális képességek fejlesztése és értékelése projekt módszerrel. (COMENIUS 1997, UIAH, Helsinki, HvkK, Arnhem, Konstfak, Stockholm).

A közoktatással kapcsolatos jogszabályalkotásban ugyancsak részt vettek a tanszék munkatársai:

- Vizuális kultúra müveltségi részterület, Nemzeti Alaptanterv, (MKM 1991/95) Bodóczky István, Zombori Béla, Kárpáti Andrea, Gaul Emil, Tatai Erzsébet

- Vizuális kultúra, érettségi vizsga általános követelményei (MKM 1996/97) Bodóczky István, Gaul Emil, Pallag Andrea, Zombori Béla

- Rajz, vizuális kultúra Kerettanterv 2000 Gaul Emil és munkatársai

- Rajz, vizuális kultúra NAT 2003 Bodóczky István vezetésével

- Rajz és vizuális kultúra tantárgy obszervációs vizsgálat (OKI 2003) Bodóczky István

- Rajz, vizuális kultúra NAT 2006 Bodóczky István

- Életvitel és gyakorlati ismeretek NAT 2003 Gaul Emil, 2006 Gaul Emil

- Vizuális kultúra, alapmüveltségi vizsga általános követelményei (OKI 1996/97) Gaul Emil, Zombori Béla, Kárpáti Andrea

- A müvészetek kompetencia hálója (EDUCATIO 2008) Bodóczky István

- Vizuális kultúra érettségi (folyamatosan) Bodóczky István, Pallag Andrea

A tanszék munkatársai vezető pozíciókat töltenek be a hazai és nemzetközi szakmai szervezetekben, kuratóriumokban:

- INSEA Nemzetközi Rajztanár Szövetség - International Society for Education Through Art

- (UNESCO-affiliált, 82 országot tömörítö, 3200 fös szervezet)

- MROE - Magyar Rajztanárok Országos Egyesülete

- Felsőoktatási Vizuális Nevelési Kollégium

- Közoktatási Modernizációs Közalapítvány Digitális Kerekasztala, szakértői testülete

- Magyar Tudományos Akadémia Pedagógiai Bizottsága

- Magyar Tehetséggondozó Társaság

- World Council of Gifted and Talented (WCGT))

- European Council for High Ability (ECHA)

Munkánk eredményét azonban elsősorban végzett hallgatóink életpályája, viszszajelzései igazolják. Köztudott, hogy a müvészeti egyetemet végzö hallgatók elsösorban müvészeti pályára készülnek. Ennek ellenére évente 40-50-en jelentkeztek a müvészképzéssel párhuzamosan folyó tanárképzésre is, évente körülbelül húszan szereztek tanári képesítést. Végzett hallgatóink művészeti tevékenységükkel párhuzamosan tanítanak rajzot és müvészettörténetet középiskolákban, vagy saját müvészeti szakterületük oktatói a múvészeti szakoktatásban, igen sokan a felsőoktatásban is. 
A mủvészeti tanárképzés során különös hangsúlyt fektetünk arra, hogy hallgatóink a müvészi és a pedagógiai tevékenységük között harmonikus viszonyt tudjanak kialakítani, hogy mindkettőt felelősségteljes alkotó tevékenységnek tekintsék, amelyek egymásra kölcsönösen termékenyítő hatást gyakorolnak, egymást kölcsönösen segítik.

A nemrég elindult MA képzés során ezt továbbra is szem előtt tartjuk, ahogyan azt is, hogy hallgatóink, akik a BA és MA müvészeti képzés során a vizuális müvészetek egy-egy szükebb területén kapnak egyetemi szintủ felkészítést, saját szakterületüket szélesebb kontextusban szemléljék, tájékozottak legyenek a vizuális kultúra területén, hogy saját szakmai tudásukra alapozva hitelesen tudjanak részt venni a szélesebb értelemben vett vizuális nevelésben is (adott esetben képesek legyenek a Nemzeti Alaptanterv szerinti müvészetek müveltségi terület nevelési feladatainak ellátására is). Ez a szakoktatásnak és a közoktatásnak egyaránt érdeke.

A design- és vizuálismüvészet-tanár képzésbe az iparmüvészeti, építőmüvészeti, képzőművészeti, film- és videomüvészeti, valamint multimédiaművészeti képzési ágban folyó müvészeti mesterszakok vagy osztatlan szakok valamelyikén folytatott tanulmányokkal párhuzamosan, vagy ezen szakokon szerzett mesterfokozat birtokában, illetve ezekkel tartalmában egyenértékủ szakismerettel lehet belépni. 